\title{
Metabolism of Subcutaneous Adipose Tissue in the Immediate Postnatal Period of Human Newborns. 1. Developmental Changes in Lipolysis and Glycogen Content
}

\author{
M. NovaK ${ }^{[53]}$ AND E. Monkus \\ Department of Pediatrics, University of Miami School of Medicine, Miami, Florida, USA
}

\begin{abstract}
Extract
The metabolism in vitro of subcutaneous adipose tissue from human newborns of different ages was investigated and comparisons were made with material taken from healthy adult volunteers. In the first hours of life, glycerol release (micromoles glycerol/100 $\mu \mathrm{g}$ DNA/90 min) by suspensions of isolated adipocytes was increased $(P<$ 0.001 ), but the response to the addition of norepinephrine was minimal. The release of free fatty acids (FFA) in relation to glycerol by suspensions of free adipocytes was considerably lower in neonates than in adults. Glycogen content of the adipose tissue between 0 and $4 \mathrm{hr}$ of age was significantly greater than in older neonates and adults $(P<0.01)$. In infants less than $4 \mathrm{hr}$ of age, glycogen content of the adipose tissue was inversely correlated with the length of labor $(P<0.05)$. Elevated reesterification of FFA seems to be related to the higher glycogen content and breakdown in subcutaneous adipose tissue immediately after birth.
\end{abstract}

\section{Speculation}

These investigations of the subcutaneous adipose tissue from human neonates show that the two basic energy substrates (carbohydrates and lipids) are closely and reciprocally related in the first hours and days of life. The findings are compatible with a transition from predominantly carbohydrate catabolism in the first hours of life to preferential utilization lipids in older neonates. Age-dependent changes in the in vitro metabolism of the adipose tissue parallel the relative importance of carbohydrates and lipids as substrates and energy sources in the total metabolism of the newborn infant. Thus, the subcutaneous adipose tissue may serve as an easily obtainable model for the study of the metabolic adaptation of the human newborn infant to extrauterine life.

\section{Introduction}

The metabolic situation of the human newborn changes abruptly when the interruption of the fetoplacental circulation cuts off the constant supply of nu- trients from the mother. He must now supply not only his basal metabolic requirements but also must find additional energy sources for respiration, digestion, and the maintenance of body temperature, and he is 
dependent wholly or partially on prenatally stored deposits until sufficient milk is consumed to meet these needs.

Both carbohydrate and lipid deposits accumulate in the human fetus during the last trimester of pregnancy $[7,15,34,41,42]$. Glucose crosses the placenta freely [28]. It is believed to be the main metabolic fuel in the fetus and, in addition, is used to lay down carbohydrate (glycogen) stores. Fat stores seem mainly to be synthesized by the fetus from glucose [28, 29, 32], but placental transfer of free fatty acids (FFA) can also occur [30].

The substantial carbohydrate reserves are believed to be exhausted shortly after birth [34]. Fat is then used as the predominant source of energy. Previous in vitro studies suggest that lipolysis, estimated from the amount of glycerol released from intact adipose tissue fragments, reaches a maximum in the first hours of human life [22]. Increasing levels of both glycerol and FFA in the blood, in contrast to the very low levels of both these substances in cord blood, also suggest increased lipolysis [19, 23, 33]. There are indications of increased oxidation of fat in older neonates such as a drop in respiratory quotient $[3,5]$ and increased blood levels of acetoacetic and $\beta$-hydroxybutyric acids $[6,17]$.

In the present study, the metabolism in vitro of subcutaneous adipose tissue from human newborns of different ages was investigated. Comparisons were made with similar studies of fat taken from adult volunteers. Suspensions of isolated cells have been used to evaluate the metabolic capabilities of adipose tissue [9, $25,31]$. With such suspensions, age-related changes in lipolysis as indicated by glycerol and FFA release were measured and the effects of norepinephrine on lipolysis were evaluated. Since the presence of carbohydrate can significantly influence fat metabolism [2, 13, 23, $35]$, age-dependent changes in the glycogen content of the adipose tissue were also determined.

\section{Materials and Methods}

Biopsies were taken from the subcutaneous adipose tissue of the buttock in normal neonates [49] and healthy adult volunteers, using a specially constructed needle [21]. The amount of tissue obtained with this technique is about $10-40 \mathrm{mg}$. Criteria for the selection of normal infants were as follows. All were products of a normal pregnancy and delivery and were in good condition at birth (Apgar scores at least 8 at $1 \mathrm{~min}$ and 9 by $5 \mathrm{~min}$ after delivery). Gestational age exceeded 37 weeks and birth weight was more than $2500 \mathrm{~g}$. None of the infants experienced any clinical difficulties during the neonatal period. Water was offered at $12 \mathrm{hr}$ and formula [44] was offered at $24 \mathrm{hr}$ of age.

\section{Suspensions of Isolated Adipose Cells}

Suspensions of free adipocytes were prepared by a microadaptation of the method of Rodbell [31], using crude bacterial collagenase [45]. The cells were washed in $0.5 \mathrm{ml}$ Krebs-Ringer phosphate buffer ( $\mathrm{pH} 7.4$ ) containing one-half the usual calcium content and $4 \%$ albumin [46].

The washing was accomplished by gently overlaying the cell suspension in the collagenase-containing medium with the washing medium, avoiding mixing the two solutions; the cells were washed by flotation with gentle stirring through an excess of the washing medium. This very careful method of washing the cells is particularly important in the preparation of isolated human adipocytes, which are more fragile and rupture more easily than the cells of other species such as the rat. The cells collect in a solid mass on the surface of the washing medium and can be transferred with a siliconized Pasteur pipette into the incubation medium.

Further details regarding the preparation of isolated adipose cell suspensions on a microscale have been reported previously [25].

\section{Release of Glycerol and FFA}

Glycerol and FFA release were estimated after incubation of the cells in $\mathbf{0 . 5} \mathrm{ml} \mathrm{Krebs-Ringer} \mathrm{phosphate}$ buffer ( $\mathrm{pH}$ 7.4) containing one-half the usual calcium concentration and $4 \%$ albumin. Concentrations of the substances in the medium were determined after 90 $\min$ incubation at $37^{\circ}$ in an Eberbach metabolic shaker at $120 \mathrm{cycles} / \mathrm{min}$. Glycerol was measured enzymatically [16] and FFA were measured colorimetrically [18]. When there was a sufficient amount of the cell suspension, it was divided into two approximately equal portions, and $2.5 \mu \mathrm{g}$ (final concentration, $5 \mu \mathrm{g} /$ $\mathrm{ml})$ norepinephrine bitartrate [47] were added to one portion prior to incubation. The cell content of suspensions was evaluated by estimation of total DNA content [25]. Results were calculated per $100 \mu \mathrm{g}$ DNA, which is equivalent to comparison on a per cell basis.

\section{Glycogen Content}

Age-related changes in glycogen content were measured in intact samples of adipose tissue (usually one cylindrical piece). After the sample was obtained from 
the subject, it was briefly placed on filter paper to remove adhering tissue fluid and was frozen immediately on Dry Ice in a small glass vial. Within $1 \mathrm{hr}$ the sample was weighed into a 3-ml glass-stoppered microcentrifuge tube and the tissue was disintegrated with a cell disrupter (Sonifer with a microhorn attachment). The lipids (which inhibit the precipitation of glycogen by ethanol) were then extracted with $1 \mathrm{ml}$ chloroformmethanol, 2:1 v/v. The sample was cooled with Dry Ice during this procedure. After $30 \mathrm{~min}$, the tube was briefly centrifuged and the chloroform-methanol containing lipids were removed with a Pasteur pipette. After saponification with $0.1 \mathrm{ml} 20 \% \mathrm{NaOH}$ for 30 $\min$ at $100^{\circ}$, the glycogen was precipitated with $0.4 \mathrm{ml}$ ethanol at $+4^{\circ}$ overnight. Centrifugation for $30 \mathrm{~min}$ at $3000 \mathrm{rpm}$ separated the precipitated glycogen. The supernatant fluid was removed with a Pasteur pipette. Washing the sediment with a few drops of absolute ethanol improved the separation of the glycogen from other possible interfering materials. The amount of glycogen in the sediment was estimated with diphenylamine reagent by the classic micromethod described by Glick [10] and Greenberg and Glick [12]. Glycogen [48] was used as a standard. The comparison of this method with enzymatically estimated glucose after hydrolysis of the precipitate with HCI was found to be satisfactory. Optical density was measured by registration of the absorption curve using a Cary model 11 recording spectrophotometer. The calibration curve was prepared simultaneously with the samples, using the same procedure. Glycogen content of samples was expressed in terms of wet weight (milligrams glycogen per gram tissue).

\section{Results}

In the first hours of life, glycerol release (micromoles glycerol per $100 \mu \mathrm{g}$ DNA/90 min) by suspensions of isolated adipose tissue cells is increased $(P<0.001$ by Student's $t$ test) but response to the addition of norepinephrine is minimal (Fig. 1). Glycerol release diminishes rapidly with age and reaches a low level by the end of the first day of life; at the same time, response to norepinephrine increases. Mean glycerol release was $1.04 \pm 0.13 \mathrm{sE}$ in the neonate less than $24 \mathrm{hr}$ of age, $0.25 \pm 0.04$ in older neonates, and $0.65 \pm 0.14$ in adults; in the presence of added norepinephrine, these means increased to $1.16 \pm 0.14$ in neonates less than 24 hr of age, $0.56 \pm 0.03$ in older neonates, and $1.36 \pm$

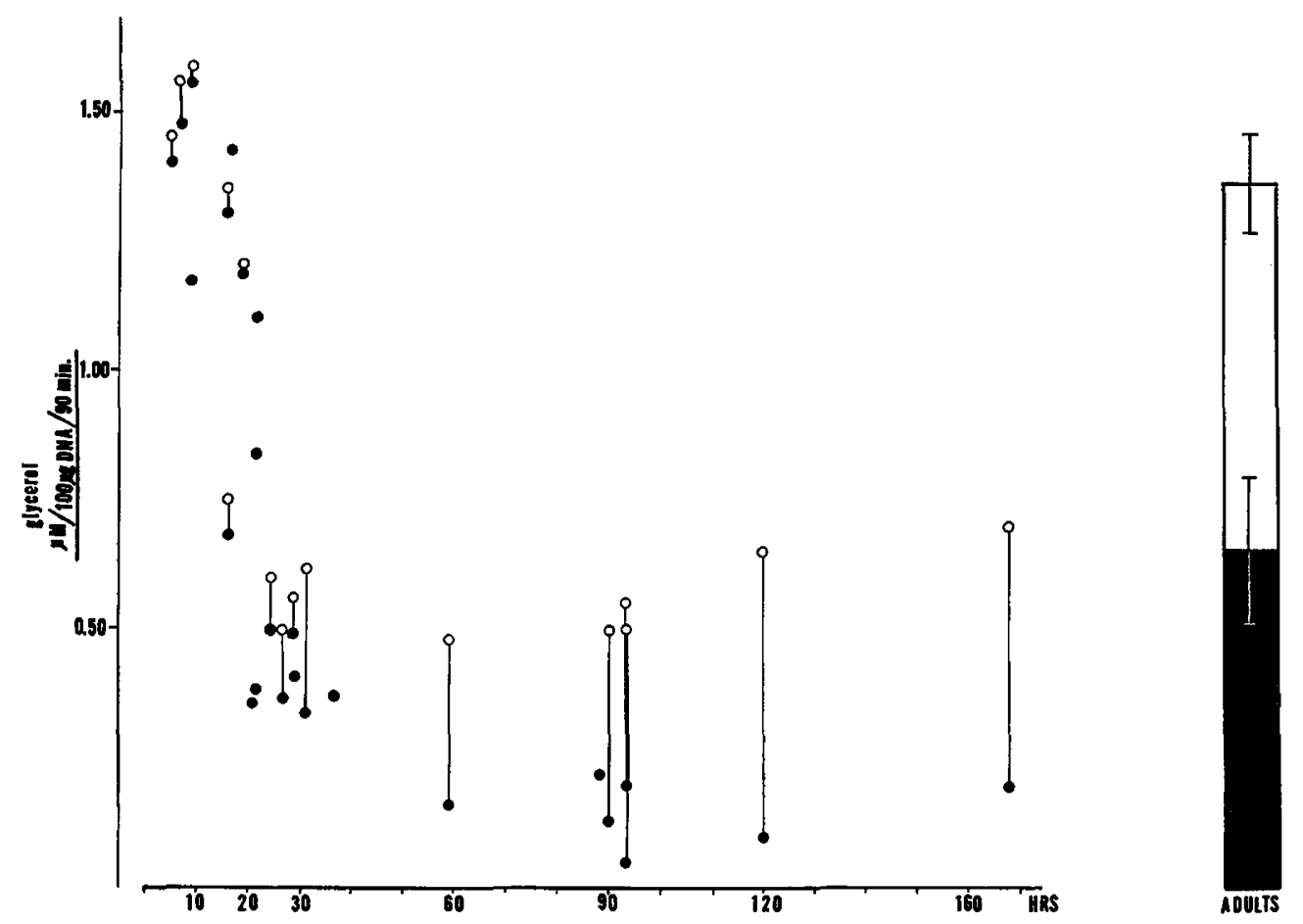

Fig. 1. Changes in release of glycerol (micromoles glycerol/100 $\mu \mathrm{g}$ DNA/90 min) by suspensions of subcutaneous adipose tissue cells in relation to age in 25 infants and 6 adults. Closed circles show the release of glycerol under basal conditions; open circles indicate release of glycerol with norepinephrine $(5 \mu \mathrm{g} / \mathrm{ml})$ added to the medium before incubation. 


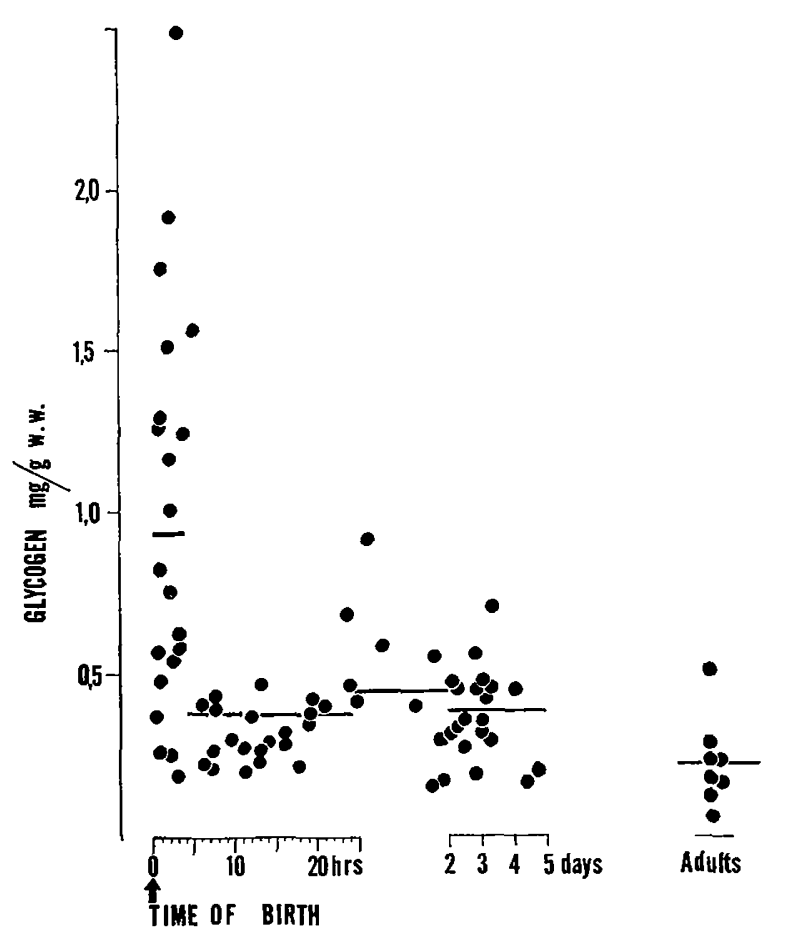

Fig. 2. Changes in glycogen content (milligrams glycogen per gram wet weight) of subcutaneous adipose tissue in relation to age in 70 neonates and 8 adults.

0.10 in adults. The percentage of increase in glycerol release was significantly greater in older infants than in those less than $24 \mathrm{hr}$ of age $(P<0.05$, Student's $t$ test for matched-pair data). Glycerol release in neonates older than $24 \mathrm{hr}$ was not significantly different than in adults either with or without norepinephrine, but examination of Figure 1 suggests that about a 2- to 3-fold greater release of glycerol occurs in adults than in neonates in the 2nd-4th day of life. The response to norepinephrine is about the same in both groups.

The release of FFA in relation to glycerol by suspensions of free adipocytes was considerably lower in neonates than in adults. In nine infants $5-32 \mathrm{hr}$ of age, the mean molar FFA/glycerol ratio was 0.94 , with a range of $0.48-1.5$. In four adults the mean FFA/glycerol ratio was 2.3, with a range of 2.1-3.2.

Glycogen content of fat tissue falls rapidly during the first hours of life (Fig. 2). Mean glycogen content (milligrams glycogen per gram wet weight) was 0.937 $\pm 0.132 \mathrm{sE}$ between 0 and $4 \mathrm{hr}$ of age, $0.389 \pm 0.054$ between 4 and $24 \mathrm{hr}$ of age, $0.436 \pm 0.088$ between 24 and $48 \mathrm{hr}$ of age, $0.378 \pm 0.031$ on the $2 \mathrm{nd}$ through the 5 th day of life, and $0.220 \pm 0.049$ in adults. Glycogen content of the adipose tissue from infants between 0 and $4 \mathrm{hr}$ of age was significantly greater than in older neonates and adults $(P<0.01$ by Student's $t$ test). Glycogen content was also greater between 24 and $48 \mathrm{hr}$ and 2 and 5 days of age than in adults $(P<$ $0.05)$. The extreme variability of glycogen content in the first $4 \mathrm{hr}$ of life is noteworthy, particularly in contrast to the constancy of the values in all other age groups. In infants less than $4 \mathrm{hr}$ of age, glycogen content of the adipose tissue was found to be inversely correlated with the length of labor $(r=-0.541, P<$ $0.05)$; that is, the longer the labor, the lower the glycogen content of the adipose tissue. A semilogarithmic analysis gives a better correlation $(r=-0.612, P<$ 0.01) (Fig. 3). There was no significant correlation in these normal full term infants between the glycogen content of the adipose tissue in the first $4 \mathrm{hr}$ of life and the age at which the sample was obtained or the birth weight of the infant.

\section{Discussion}

Glycerol release from adipose tissue in vitro is a measure of the rate of glyceride breakdown in the tissue [39]. Glycerol is not the immediate substrate for reesterification of FFA; it must first be converted to $\alpha$-glycerophosphate by a reaction catalyzed by the enzyme glycerokinase, activity of which is relatively low in neonatal subcutaneous adipose tissue, even though it is probably higher in newborn infants than in adults [20]. Hence, the re-utilization of glycerol by this tissue is probably not a quantitatively significant factor. This implies that increased in vitro glycerol release indicates increased lipolysis. The higher glycerol release found in isolated adipose tissue cells of newborn infants during the first postnatal hours confirms previous findings of increased glycerol content and release in intact adipose tissue samples [22]. The period during which glycerol release is increased is brief; in infants more than 2 days of age, it is less than in fasting adults.

Elevated lipase activity seems to be the simplest explanation of the relatively high glycerol release in the first hours of life. This would mean that the activity of either the hormone-sensitive (triglyceride) lipase or the mono- and diglyceride lipase may be increased, or, in fact, both forms of lipase may be more active. The decreased in vitro response to norepinephrine during this period would be consistent with the concept that lipolysis is proceeding so rapidly that norepinephrine can cause only a small further increase in fat mobilization. Based on observations of van Duyne $e t$ al. of fetal and newborn lambs [36-38], fat mobilization in new- 


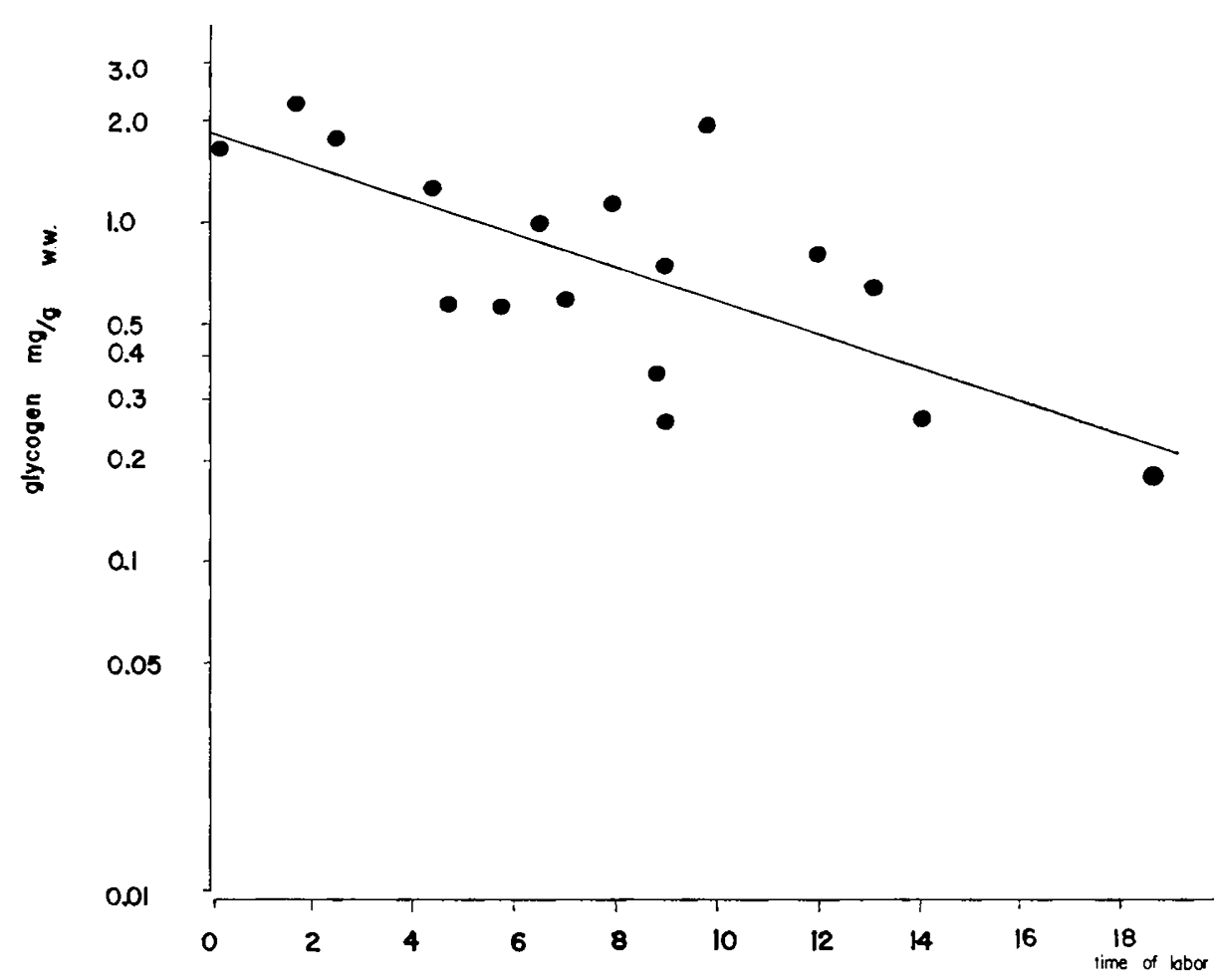

Fig. 3. Effect of length of labor on glycogen content (milligrams glycogen per gram wet weight) of the subcutaneous adipose tissue in neonates during the first $4 \mathrm{hr}$ of life.

born animals is dependent on increased activity of the sympathetic nervous system; transplacental passage of catecholamines from mother to fetus is also possible [43]. Some mechanism related to the stress of labor and delivery may trigger the increased lipolysis in the first hours of life. In particular, it is thought that hypoxia and hypercapnia or acidosis, or both, during labor and delivery and persisting in the first hours of life may increase catecholamine secretion at this time [4]. Although several hormones are known to influence lipolysis in human adipose tissue by activation of adenyl cyclase $[8,27,39]$, the concept that a catecholamine may be involved in this particular case is quite plausible. It may be assumed that the in vitro response of the adipose tissue reflects the level of hormonal and autonomic stimulation to which the adipose tissue was being subjected at the time of sampling.

The results of this study, as well as a previous in vitro study of the metabolism of intact adipose tissue samples [24], offer support for the concept that reesterification in the subcutaneous adipose tissue of the young neonate is increased. The FFA/glycerol ratio was found to be low in neonates less than $24 \mathrm{hr}$ of age; inasmuch as FFA reesterification proceeds concomi- tantly with lipolysis, the net production of FFA in relation to glycerol, i.e., the molar ratio of FFA/glycerol, should reflect the balance between rates of reesterification and glyceride breakdown. The decreased FFA/glycerol ratio in neonates in the first hours of life would indicate that not all of the FFA produced by lipolysis are being released from the cell, but that some are immediately used within the cell for reesterification. Oxidation and de novo synthesis of FFA may also affect the ratio of $\mathrm{FFA} /$ glycerol. In the adult, these reactions proceed very slowly under the conditions of this study $[1,11]$. Similar studies have never been performed in neonates; hence, a possible influence of oxidation and de novo synthesis of FFA on the FFA/glycerol ratio in this study cannot be evaluated. The opinion that FFA are being retained by reesterification in the adipose tissue just after birth is supported, however, by the finding that small fragments of adipose tissue from neonates in the first hours of life were able to incorporate more ${ }^{14} \mathrm{C}$-labeled palmitic acid into triglycerides than those from older neonates and adults [14].

It seems, therefore, that the process of reesterification of FFA is high in the subcutaneous adipose tissue 
of infants less than $24 \mathrm{hr}$ of age. This elevated reesterification may be related to the high glycogen content of the adipose tissue immediately after birth, for in the subcutaneous adipose tissue the immediate substrate for the reesterification of FFA is $\alpha$-glycerophosphate derived from glycolysis rather than the glycerol formed by the lipolysis of triglycerides. Glucose would have to have been of intracellular origin since no exogenous glucose was added with the incubation medium. The very young neonate was found to have increased carbohydrate availability in the form of stored glycogen, inasmuch as the mean glycogen content of the adipose tissue in the first $4 \mathrm{hr}$ of life was about 2.5 times that in older infants. This glycogen should be available for utilization within the cells since glucose-6-phosphatase activity is described as low or missing from subcutaneous adipose tissue [40]. Glycogen stores, however, fell very rapidly in the first $4 \mathrm{hr}$ of life, yet glycerol release continued to be increased until at least $24 \mathrm{hr}$ of age. Thus the products of glycogenolysis ( $\alpha$-glycerophosphate) may facilitate the reesterification of FFA more in the first $24 \mathrm{hr}$ of life than later. We have no information regarding the availability of glucose or other substrates of the Embden-Meyerhof pathway or of the pentose shunt in the adipose tissue during the 1st day of life, which might further contribute to an explanation of the mechanism of the increased lipolysis and its association with the increased reesterification of FFA found in this age group.

Comparison of the in vitro metabolism of the adipose tissue of neonates and adults showed the adipocyte of the neonate to be nearly as active metabolically as the much larger cell of the adult. Although the volume of the neonatal adipocyte is only about onesixth-one-seventh that of the adult [26], the rate of lipolysis was about one-half-one-third that found in the adult. Except for the very young neonate less than $24 \mathrm{hr}$ of age, the response to norepinephrine was about the same in both groups. The capability to reesterify FFA is probably greater in the adipose cell of the neonate than in the adult cell.

These in vitro studies of normal human newborns indicate that age-dependent changes in the metabolism of the adipose tissue in human neonates correlate well with known observations regarding the metabolism of other tissues and of the body as a whole. Glycogen content in several tissues (liver and cardiac muscle) is rapidly depleted in the first hours of life [34]. In adipose tissue, glycogen concentration is quantitatively much lower but a similar decline in the glycogen content of this tissue was found in the first hours of life.
At the same time, blood sugar falls to a low level and serum glycerol and FFA increase. When carbohydrate deposits are exhausted, the older neonate switches to utilization of lipid stores until there is sufficient oral caloric intake to supply energy needs. The increase in ketone bodies in the blood $[6,17]$ and the decrease in respiratory quotient $[3,5]$ support this view. In adipose tissue, the increased lipolysis observed during the 1st day of life indicates that this tissue is adapted to supply the rest of the organism with glycerol immediately after birth. Free fatty acids should also be more readily available, perhaps somewhat later if reesterification is indeed increased during the first hours of life.

\section{Summary}

(l) Glycerol release (micromoles per $100 \mu \mathrm{g}$ DNA/90 min) from suspensions of free adipose cells was elevated in the 1st day of life but was less activated by norepinephrine than in older neonates and adults. (Metabolic values were standardized to total DNA content as an index of the number of cells.) The present study confirms previous findings in intact adipose tissue fragments, which indicated relatively increased glycerol release (micromoles per gram tissue wet weight per $90 \mathrm{~min}$ ) in young neonates and also showed the increased glycerol release to be a property of the individual adipose cell.

(2) In the adult, FFA release was equivalent to glycerol release. In the young neonate, FFA release was relatively much less. These findings are in agreement with previous results using fragments of intact adipose tissue.

(3) Mean glycogen content of adipose tissue in the first $4 \mathrm{hr}$ of life was about twice that of older newborns up to 5 days of age. Mean glycogen content of adipose tissue was also greater in neonates than in adults. Glycogen content in the first $4 \mathrm{hr}$ of life was inversely correlated with the length of labor.

\section{References and Notes}

I. BALL, E. G., AND Jungas, R. L.: Net gas exchange and oxygen consumption. In: A. E. Renold and G. F. Cahill: Handbook of Physiology, Sect. 5, Adipose Tissue, Chapt. 36, p. 355. (American Physiology Society, Washington, 1965).

2. Bally, P. R., Cahill, C. F., and Leboeuf, B.: Studies on rat adipose tissue in vitro. V. Effects of glucose and insulin on the metabolism of palmitate-1-C ${ }^{14}$. J. Biol. Chem., 235: 333 (1960).

3. Benedict, F. G., AND TALBOT, F. B.: The physiology of the newborn infant, character and amount of catabolism. Carnegie Inst., Washington. Publ. 233. (1915).

4. Cheek, D. B., Malinek, M., and Fraillon, J. M.: Plasma adrenaline and noradrenaline in the neonatal period, and 
infants with respiratory distress syndrome and placental insufficiency. Pediatrics, 31: 374 (1963).

5. Cross, K. W., Tizard, J. P. M., and Trydhall, D. R.: The gaseous metabolism of the newborn infant. Acta Paediat. Scand., 46: 265 (1957).

6. Dean, M., and Barker, G.: Lipid metabolism in the newborn (Abstract). p. 227. (Society for Pediatric Research, Atlantic City, 1970).

7. Ferling, H.: Beitrage zur Physiologie des placentaren Stoffverkehrs. Arch. Gynaekol., 11: 523 (1877).

8. Frerichs, H., and Ball, E. G.: Studies on the metabolism of adipose tissue. XI. Activation of phosphorylase by agents which stimulate lipolysis. Biochemistry, 1:50 (1962).

9. Galton, D. J., ANd Bray, G. A.: Studies on lipolysis in human adipose cells. J. Clin. Invest., 46: 621 (1967).

10. GLICK, D.: Quantitative Chemical Techniques of Histo- and Cytochemistry, p. 247. (Wiley and Sons, New York, 1949).

11. Goldrick, R. B., Ashley, B. C. E., AND Lloyd, M. L.: Effects of prolonged incubation and cell concentration on lipogenesis from glucose in isolated human omental fat cells. J. Lipid Res., 10: 253 (1969).

12. Greenberg, L. J., AND Glick, D.: Studies in histochemistry. LXVIII. Determination of glycogen in microgram samples of tissue, quantitative histologic distribution in the rat adrenal, and influence of ACTH. Biochemistry, 1: 452 (1962).

13. Gurman, A., AND Shafir, E.: Metabolic influences on enzymes of glycogen synthesis and breakdown in adipose tissue. Amer. J. Physiol., 207: 1215 (1964).

14. Hahn, P., Novak, M., and Melichar, V.: Incorporation of ${ }^{1-14}$-C-palmitic acid into the lipids of human adipose tissue in vitro during postnatal development. Physiol. Bohemoslov., 15: 493 (1966)

15. HaworTh, J. C.: Carbohydrate metabolism in the fetus and newborn. In: D. Y. Hsia: The Pediatric Clinics of North America, Vol. 12, no. 3, p. 573. (Saunders, Philadelphia, 1965).

16. Kreutz, F. H.: Enzymatische Glycerinbestimmung. Klin. Wochenschr., 40: 362 (1962).

17. Melichar, V., Drahota, Z., and Hahn, P.: Changes in the blood levels of acetoacetate and ketone bodies in newborn infants. Biol. Neonatorum, 8: 348 (1965).

18. Novak, M.: A colorimetric ultramicromethod for the determination of unesterified fatty acids. J. Lipid Res., 6: 91 (1965).

19. NovaK, M., HahN, P., aNd Melichar, V.: Postnatal changes in the blood serum content of glycerol and fatty acids in human infants. Biol. Neonatorum, 7: 179 (1964).

20. Novak, M., Hahn, P., aNd Melichar, V.: Incorporation of glycerol $1-3-{ }^{14} \mathrm{C}$ into triglycerides of subcutaneous adipose tissue in the newborn. Biol. Nconatorum, 12: 287 (1968).

21. Novak, M., and Melichar, V.: Technique for sampling of human adipose tissue. Physiol. Bohemoslov., 12: 84 (1963).

22. Novak, M., Melichar, V., ANd HahN, P.: Changes in the content and release of glycerol in subcutaneous adipose tissue of newborn infants. Biol. Neonatorum, 8: 253 (1965).

23. Novak, M., Melichar, V., Hahn, P., and Koldovsky, O.: Levels of lipids in the blood of newborn infants and effect of glucose administration. Physiol. Bohemoslov., 10: 488 (1961).

24. NovaK, M., Melichar, V., Hahn, P., AND Koldovsky, O.: Release of FFA from adipose tissue obtained from newborn infants. J. Lipid Res., 6: 91 (1965).

25. Novak, M., AND Monkus, E.: Determination of the oxygen consumption of isolated adipose tissue cells obtained by needle trocar puncture. Anal. Biochem., 36: 454 (1970).

26. Novak, M., Monkus, E., ANd Pardo, V.: Human neonatal subcutaneous adipose tissue: function and ultrastructure. Submitted for publication.

27. Oestman, J., Efendic, S., And Arner, P.: Catecholamines and metabolism of human adipose tissue. Acta Med. Scand., 186: 241 (1969).

28. PAGE, E. W.: Transfer of materials across the human placenta. Amer. J. Obstet. Gynecol., 74: 705 (1957).

29. PopJak, G.: The origin of fetal lipids. Cold Spring Harbor Symp. Quant. Biol., 14: 200 (1954).

30. Portman, O. W., Behrman, R. E., and Soltys, P.: Transfer of free fatty acids across the primate placenta. Amer. J. Physiol., 216: 143 (1969).

31. RodbelL, M.: Metabolism of isolated fat cells. I. Effects of hormones on glucose metabolism and lipolysis. J. Biol. Chem., 239: 375 (1964).

32. Roux, J. F., Glicorlan, A., and Takeda, Y.: In vitro "lipid" metabolism in the developing human foctus. Nature, 216: 819 (1967).

33. Roux, J. F., Romney, S. L., ANd Hausinger, A.: Plasma free fatty acids and glucose concentrations in the human fetus and newborn exposed to various environmental conditions. Amer. J. Obstet. Gynecol., 97: 268 (1967).

34. Shelley, H. J.: Glycogen reserves and their changes at birth and in anoxia. Brit. Med. Bull., 17: 137 (1961).

35. Tuerkischer, E., ANd Wertheimer, E.: Factors influencing deposition of glycogen in adipose tissue of rats. J. Physiol. (London), 104: 361 (1964).

36. Van Duyne, C. M., and Havel, R. J.: Plasma unesterified fatty acid concentration in fetal and neonatal life. Proc. Soc. Exp. Biol. Med., 102: 599 (1959).

37. Van Duyne, C. M., and Havel, R. J.: The plasma lipids in pregnancy and in newborn. Obstet. Gynecol., 3: 326 (1960).

38. Van Duyne, C. M., Parker, H. L., Havel, R. J., and Holm, L. W.: Free fatty acid metabolism in fetal and newborn sheep. Amer. J. Physiol., 199: 987 (1960).

39. Vaughan, M., and Steinberg, D.: Effect of hormones in lipolysis and esterification of free fatty acids during incubation of adipose tissue in vitro. J. Lipid Res., 4: 193 (1963).

40. Weber, G., Hird, H. J., Stamm, N. B., and Wagle, D. S.: Enzymes involved in carbohydrate metabolism in adipose tissue. In: A. E. Renold and G. F. Cahill: Handbook of Physiology, Sect. 5, Adipose Tissue, Chapt. 23, p. 225. (American Physiological Society, Washington, 1965).

41. Widdowson, E. M.: Chemical composition of newly born mammals. Nature, 166: 626 (1950).

42. Wolf, H., AND LöHR, H.: Fettinfusionen bei Frühgeborenen am ersten Lebenstag. Monatsschr. Kinderheilk., 116: 262 (1968).

43. Zuspan, F. P., Whaley, W. H., Nelson, G. H., and Ahlquist, R. P.: Placental transfer of epinephrine. I. Maternal-fetal metabolic alterations of glucose and nonesterified fatty acids. Amer. J. Obstet. Gynecol., 15: 284 (1966).

44. Similac, $13 \mathrm{cal} / \mathrm{oz}$.

45. Worthington Biochemical Corporation, Freehold, N. J.

46. Sigma Fraction V powder, Sigma Chemical Company, St. Louis, Mo.

47. Levophed, Winthrop Laboratories, N. Y.

48. AR, Fisher Scientific Company, Pittsburgh, Penna. 
49. Consent to study the infants was given by the mother before obtaining the fat biopsies.

50. The authors thank Mrs. Vera Ondricek and Mrs. Carmelina Guerra for their excellent technical assistance.

51. Presented in part at the Annual Meeting of the Society for Pediatric Research, Atlantic City, May, 1970.

52. Supported by University of Miami School of Medicine General Research Support Fund Grant no. FR-05353, from
October, 1969, through September, 1970. Dr. Monkus was a recipient of Training Grant no. HD-76-06, from the National Institutes of Health, through June 30, 1970.

53. Requests for reprints should be addressed to: Milan NovaK, Ph.D., Department of Pediatrics, University of Miami School of Medicine, P.O. Box 875, Biscayne Annex, Miami, Fla., 33152 (USA).

54. Accepted for publication June 4, 1971. 